\title{
USP46 wt Allele
}

National Cancer Institute

\section{Source}

National Cancer Institute. USP46 wt Allele. NCI Thesaurus. Code C158825.

Human USP46 wild-type allele is located in the vicinity of $4 \mathrm{q} 12$ and is approximately $68 \mathrm{~kb}$ in length. This allele, which encodes ubiquitin carboxyl-terminal hydrolase 46 protein, is involved in protein modification and neurotransmitter-dependent behavior. 